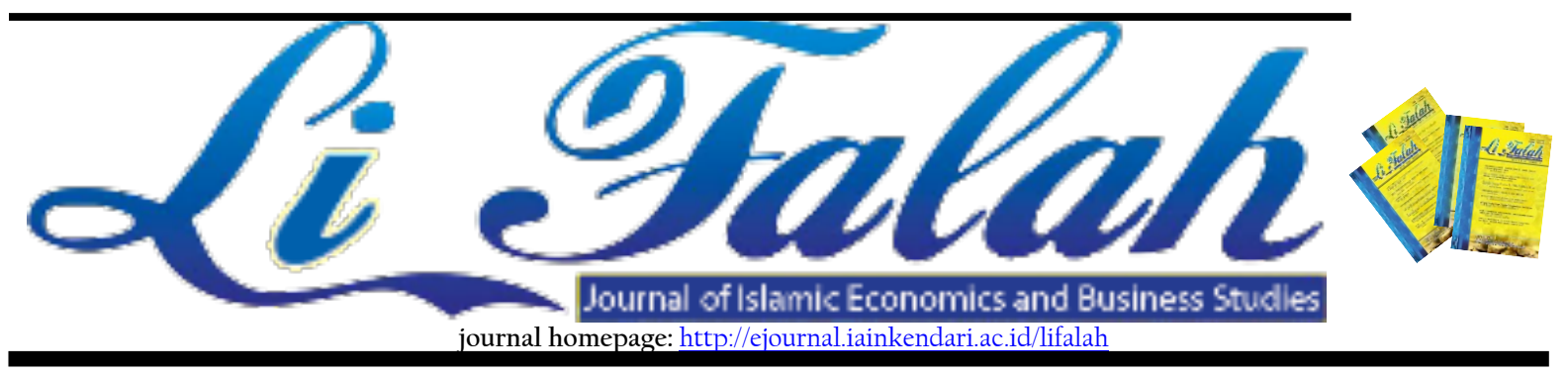

\title{
EVALUASI SISTEM PENGENDALIAN INTERN PENERIMAAN KAS PADA PERUSAHAAN DAERAH AIR MINUM (PDAM) BUTON SELATAN
}

\author{
Randy Ariyadita Putra ${ }^{1}$, Rafida Bangki ${ }^{2}$, Hasan Taleba ${ }^{3}$ \\ 1, Institut Agama Islam Negeri Kendari, Universitas Nahdlatul Ulama Sulawesi Tenggara ${ }^{2},{ }^{3}$ Universitas \\ Nahdlatul Ulama Sulawesi Tenggara \\ e-cmail: * *irandy.ap@iainkendari.ac.id, ${ }^{2}$ januarifida@gmail.com, ${ }^{3}$ hasanjoko01@gmail.com
}

\begin{tabular}{|c|c|}
\hline ARTICLE INFO & A B S T R A C T \\
\hline Keywords: & Artikel ini adalah hasil penelitian yang \\
\hline Sistem Pengendalian Intern, & mengevaluasi sistem pengendalian intern \\
\hline Penerimaan Kas & penerimaan kas pada PDAM Buton Selatan, \\
\hline & dimana dalam praktiknya ditunjukkan pada unsur \\
\hline JEL classification: & pengendalian intern yaitu dalam melakukan \\
\hline & pemeriksaan internal atas transaksi penerimaan \\
\hline & kas tidak dilakukan oleh orang yang \\
\hline & berpengalaman. Penelitian ini memiliki tujuan \\
\hline DOI. & pengendalian intern penerimaan kas vang \\
\hline DU1. & diterapkan oleh PDAM Buton Selatan, 2) untuk \\
\hline & mengetahui sistem pengendalian intern \\
\hline & penerimaan kas yang diterapkan oleh PDAM Buton \\
\hline & Selatan, 3) untuk mengetahui evaluasi penerapan \\
\hline & sistem pengendalian intern penerimaan kas oleh \\
\hline & PDAM Buton Selatan. Penelitian ini merupakan \\
\hline & penelitian kualitatif. Penelitian ini menggunakan \\
\hline & kuesioner, wawancara, observasi dan dokumentasi \\
\hline & dalam pengumpulan data. Hasil penelitian ini \\
\hline & menunjukkan bahwa di PDAM Buton Selatan \\
\hline & dalam struktur organisasi baik sekali, sistem \\
\hline & wewenang dan prosedur pencatatan baik sekali, \\
\hline & praktek yang sehat baik, dan karyawan yang \\
\hline & mutunya sesuai dengan tanggung jawabnya \\
\hline & sedang, hal ini menunjukkan bahwa sistem \\
\hline & pengendalian intern penerimaan kas di PDAM \\
\hline & Buton Selatan baik dengan total bobot penilaian \\
\hline & hasil kuesioner adalah $79,16 \%$ berada di kisaran \\
\hline & poin $61 \%-80 \%$. \\
\hline
\end{tabular}




\section{Introduction}

Sistem pengendalian intern kas dilaksanakan untuk menghindari terjadinya kebocoran agar tidak adanya kejahatan ataupun kecurangan yang terjadi dalam perusahaan, mengingat kas ini sangat mudah disembunyikan dan dipindah tangankan, sehingga selalu menjadi sasaran penyelewengan pada penerimaan kas dan juga untuk mengetahui tingkat keefektifan sistem pengelolaan manajemen keuangan yang telah dilaksanakan.

Mulyadi (2002) Pengendalian Intern meliputi struktur organisasi, metode dan prosedur yang dikoordinasikan dan diterapkan dalam perusahaan dengan tujuan untuk mengamankan harta milik perusahaan, mengecek ketelitian dan keandalan data akuntansinya, mendorong efisiensi, dan mendorong dipatuhinya kebijakan manajemen yang telah ditetapkan sebelumnya. Sistem Pengendalian Intern (SPI) merupakan unsur penting yang harus melekat dalam suatu sistem akuntansi, sebab pengendalian intern mengarahkan kegiatan organisasi untuk mencapai tujuannya. Agar berjalan baik, suatu sistem pengendalian intern harus memiliki unsur-unsur pokok yaitu sebagai berikut:

1. Struktur organisasi yang memisahkan tanggung jawab fungsional secara tegas;

2. Sistem wewenang dan prosedur pencatatan yang memberikan perlindungan yang cukup terhadap kekayaan, utang, pendapatan dan biaya;

3. Pelaksanaan kerja yang sehat dalam melaksanakan tugas dan fungsi setiap unit organisasi;

4. Karyawan yang berkualitas sesuai dengan tanggung jawab yang dipikulnya.

PDAM Buton Selatan memiliki kegiatan manajemen yang berkaitan dengan bidang sumber daya air dan keuangan. Didalam menjalankan kegiatannya, PDAM Buton Selatan memerlukan beberapa alat pendukung yang dapat meningkatkan kualitas manajemen keuangan seperti kepemimpinan dan struktur organisasi yang baik, rancangan anggaran sistem serta administrasi dan sistem pengelolaan manajemen keuangan yang baik. Sistem pengelolaan manajemen keuangan yang baik perlu memperhatikan cara pengelolaan manajemen keuangan dan pelaporan informasi keuangan PDAM Buton Selatan. Informasi keuangan PDAM Buton Selatan berguna baik untuk pihak intern yaitu dalam proses pengambilan keputusan serta dalam melakukan pemeriksaan pengelolaan keuangan maupun pihak ekstern yaitu dalam menilai, menganalisis dan mengevaluasi perusahaan tersebut.

Dalam mewujudkan pengelolaan manajemen keuangan yang baik, PDAM Buton Selatan memerlukan dana untuk memenuhi kebutuhan dalam melaksanakan kegiatan-kegiatan pelayanan misalnya untuk pembelian barang, pembayaran listrik, gaji pegawai dan lain-lain. PDAM Buton Selatan dalam memperoleh dana diperoleh dari bantuan Pemerintah Daerah yaitu APBD dan Dana Hibah dari Pemerintah Pusat yang diperuntukkan bagi masyarakat yang berpenghasilan rendah. Didalam mengatur dan mengelola dana yang telah terkumpul, PDAM Buton Selatan memerlukan informasi keuangan yang akurat untuk menjalankan kegiatankegiatannya, sehingga pengelolaan keuangan PDAM Buton Selatan tidak lepas dari penggunaan Sistem Pengendalian Intern.

Peneliti memandang sistem pengendalian intern yang baik merupakan hal yang paling penting dalam perusahaan, mengingat terwujudnya visi dari sebuah perusahaan sangatlah tergantung dari bagaimana baiknya sistem pengendalian intern yang diterapkan. Demikian juga halnya dengan PDAM Buton Selatan, dimana sistem pengendalian intern yang ada dalam PDAM Buton Selatan ini sebenarnya sudah baik, yaitu dengan adanya pemeriksaan secara independent yang dilakukan oleh bagian pengawas setiap tiga bulan dan juga telah adanya perhitungan saldo secara periodik untuk menjaga kekayaan organisasi dan mengecek ketelitian dan keandalan catatan akuntansi pada penerimaan kas yang harus dilaksanakan secara teliti karena modal yang jumlahnya terbatas harus digunakan seefektif mungkin sesuai dengan tujuan usahanya untuk meningkatkan kesejahteraan para pegawainya. Namun yang namanya perusahaan tentulah tetap mempunyai kelemahan dan kekurangan, demikian juga dengan PDAM Buton Selatan, dimana dalam praktiknya ditunjukkan pada unsur 
pengendalian intern yaitu dalam melakukan pemeriksaan internal atas transaksi penerimaan kas tidak dilakukan oleh orang yang berpengalaman. Hal ini bertolak belakang dengan prinsip pokok pengendalian intern. Akan tetapi hal ini dapat teratasi jika pemimpin perusahaan dalam hal ini adalah Direktur PDAM Buton Selatan atau bagian keuangan dapat mengawasi dan melaksanakan tugas tersebut dengan baik.

\section{Literature Review}

Menurut Romney dan Steinbart (2015) sistem adalah serangkaian dua atau lebih komponen yang saling terkait dan berinteraksi untuk mencapai suatu tujuan. Menurut Mulyadi (2016) sistem dapat diartikan sebagai sekelompok unsur yang erat berhubungan satu dengan yang lainnya yang berfungsi bersama-sama untuk mencapai tujuan tertentu.

Theodorus (2014) Pengendalian internal dirancang, diimplementasi dan dipelihara oleh TCwG (Those Charge with Governance), manajemen, dan karyawan lain untuk menangani risiko bisnis dan risiko kecurangan yang diketahui (identified business and fraud risks) mengancam pencapaian tujuan entitas, seperti pelaporan keuangan yang andal. Pengendalian selalu merupakan jawaban (response) untuk menangkal (mitigate) suatu ancaman (kemungkinan terjadinya risiko). Pengendalian internal merupakan jawaban manajemen untuk menangkal risiko yang diketahui, atau dengan perkataan lain untuk mencapai suatu tujuan pengendalian (control objective). Ada hubungan langsung antara tujuan entitas dan pengendalian internal yang diimplementasikannya untuk mencapai tujuan entitas. Sekali tujuan entitas ditetapkan, manajemen dapat menentukan potensi risiko yang dapat menghambat tujuan tadi. Dengan informasi ini, manajemen dapat menyusun jawaban yang tepat, termasuk merancang pengendalian internal.

Menurut Anastasya dan Lilis (2015) pengendalian intern merupakan kegiatan yang sangat penting sekali dalam pencapaian tujuan usaha. Demikian pula dunia usaha mempunyai perhatian yang makin meningkat terhadap penegendalian intern. Pengendalian intern adalah semua rencana organisasional, metode dan pengukuran yang dipilih oleh suatu kegiatan usaha untuk mengamankan harta kekayaanya, mengecek keakuratan dan keandalan data akuntansi usaha tersebut, meningkatkan efisiensi operasional dan mendukung dipatuhinya kebijakan manajerial yang telah ditetapkan.

Menurut Amin Widjaja Tunggal (2013) tujuan pengendalian intern yaitu sebagai berikut:

a) Keandalan dan integritas informasi. Komponen pengendalian "informasi dan komunikasi" secara utuh menjelaskan dan mencakup tujuan tersebut.

b) Ketaatan dengan kebijakan rencana dan prosedur organisasi. Komponen pengendalian "aktivitas pengendalian" menunjukan bahwa penetapan dan ketaatan yang diperkuat terhadap kebijakan dan prosedur untuk mempertahankan organisasi dalam jalur terhadap pencapaian tujuan.

c) Mengamankan harta, pemakaian sumber daya yang ekonomis dan efisiensi dan pencapaian tujuan dan sasaran yang ditetapkan. Ketiga tujuan tersebut secara langsung dinyatakan dalam halaman pertama Executive Summary COSO: "kategori pertama (efektivitas dan efisiensi operasi) menyatakan tujuan utama dari entitas, termasuk kinerja dan tujuan kemampuan labaan dan pengamanan sumber daya".

d) Kepatuhan terhadap hukum, regulasi, dan kontrak. 


\section{Research Method}

\subsection{Pendekatan Penelitian}

Pendekatan penelitian yang digunakan oleh peneliti adalah pendekatan kualitatif. Penelitian dengan pendekatan kualitatif juga dapat dimaknai sebagai rangkaian kegiatan penelitian yang mengembangkan pola pikir induktif dalam menarik suatu kesimpulan dari suatu fenomena tertentu. Pola berpikir induktif ini adalah cara berpikir dalam rangka menarik kesimpulan dari sesuatu yang bersifat khusus kepada yang sifatnya umum. Dengan pendekatan ini peneliti dapat memperoleh gambaran yang lengkap dari permasalahan yang dirumuskan dengan memfokuskan pada proses dan pencarian makna dibalik fenomena yang muncul dalam penelitian, dengan harapan agar informasi yang dikaji lebih bersifat komprenshif, mendalam, alamiah dan apa adanya. Dengan kata lain, penggunaan pendekatan kualitatif dalam penelitian ini dimaksudkan untuk mengungkapkan gejala secara holistik dan kontekstual (Sugiyono, 2010).

\subsection{Jenis Data Penelitian}

Jenis penelitian ini termasuk jenis penelitian deskriptif kualitatif, yaitu penelitian yang terbatas pada usaha untuk mengungkapkan suatu masalah atau keadaan atau peristiwa sebagaimana adanya sehingga bersifat hanya untuk mengungkapkan fakta (fact finding) dan tidak bermaksud untuk menguji hipotesis, membuat prediksi, maupun mempelajari implikasi. Hasil penelitian ini ditekankan pada memberikan gambaran secara objektif tentang keadaan sebenarnya dari objek yang diselidiki.

\subsection{Sumber Data Penelitian}

Data yang digunakan dalam penelitian ini adalah data kualitatif. Berdasarkan cara memperolehnya, data ini dikelompokkan menjadi dua jenis yaitu (Indriantoro dan Supomo, 2009):

1. Data Primer merupakan sumber data penelitian yang diperoleh secara langsung dari sumber asli (tidak melalui media perantara). Data primer secara khusus dikumpulkan oleh peneliti untuk menjawab pertanyaan penelitian. Data primer dapat berupa opini subjek (orang) secara individual atau kelompok, hasil observasi terhadap suatu benda (fisik), kejadian atau kegiatan, dan hasil pengujian.

2. Data Sekunder merupakan sumber data penelitian yang diperoleh peneliti secara tidak langsung melalui media perantara (diperoleh dan dicatat oleh pihak lain). Data sekunder umumnya berupa bukti, catatan atau laporan historis yang telah tersusun dalam arsip (data dokumenter) yang dipublikasikan dan yang tidak dipublikasikan.

\subsection{Teknik Penentuan Informan Atau Responden}

Untuk menentukan informan dalam penelitian ini, peneliti memilih Teknik purposive sampling dan Snowball Sampling. Teknik purposive sampling adalah teknik pengambilan sampel sumber data dengan pertimbangan tertentu. Pertimbangan tertentu ini, misalnya orang tersebut yang dianggap paling tahu tentang apa yang kita harapkan, atau mungkin dia sebagai penguasa sehingga akan memudahkan peneliti menjelajahi objek/situasi sosial yang diteliti. Dalam teknik purpose sampling peneliti memilih subyek penelitian dengan tujuan untuk menentukan informan kunci (key informan) yang sesuai dengan fokus penelitian yangdilakukan secara sengaja tanpa dibuat-buat untuk mendapatkan kekuatan akurasinya. Sedangkan untuk menambah kredibilitas data, peneliti juga menggunakan teknik snowball sampling yang mana bertujuan untuk mengembangkan informasi dari informan yang telah ditentukan (Sugiyono, 2014). 


\subsection{Instrumen Penelitian}

Penelitian kualitatif instrument utamanya adalah peneliti sendiri, namun selanjutnya setelah fokus penelitian menjadi jelas, maka kemungkinan akan dikembangkan instrument penelitian sederhana, yang diharapkan dapat melengkapi data dan membandingkan dengan data yang telah ditemukan. Peneliti kualitatif yang merubah masalah atau ganti judul penelitiannya setelah memasuki lapangan penelitian atau setelah selesai, merupakan peneliti kualitatif yang lebih baik, karena peneliti dipandang mampu melepaskan apa yang telah dipikirkan sebelumnya, dan selanjutnya mampu melihat fenomena secara lebih luas dan mendalam sesuai dengan apa yang terjadi dan berkembang pada situasi sosial yang diteliti (Sugiyono, 2010).

\subsection{Teknik Pengumpulan Data}

Dalam penelitian ini, teknik pengumpulan data yang dapat digunakan adalah riset lapangan yaitu riset yang dilakukan dengan mendatangi secara langsung lapangan yang menjadi objek penelitian yaitu Kantor PDAM Buton Selatan. Dalam riset ini, peneliti menggunakan beberapa metode pengumpulan data yaitu: wawancara, dokumentasi, kuesioner dan observasi.

\subsection{Teknik Analisis Data}

Teknik analisis data dalam penelitian ini menggunakan teknik analisis data yang mengacu pada model analisis data Miles dan Huberman. Menurut Miles dan Huberman (2014) analisis data kualitatif terdiri dari tiga tahap, antara lain sebagai berikut:

a. Kondensasi data adalah suatu kegiatan memilih dan pemusatan hal-hal yang pokok terkait data untuk penyederhanaan, abstraksi, dan transformasi data mentah untuk memperoleh informasi yang sesuai dan tepat. Dengan demikian, data yang telah dipilih akan memberikan gambaran yang lebih jelas dan mempermudah peneliti untuk melakukan pengumpulan data selanjutnya.

b. Penyajian Data dapat dilakukan dalam bentuk tabel, grafik, phie chard, dengan memberikan uraian angka-angka dan perhitungan dalam bentuk teks yang bersifat naratif.

c. Penarikan Kesimpulan/ Verifikasi. Kesimpulan dalam penelitian kualitatif merupakan temuan-temuan baru yang sebelumnya belum pernah ada. Temuantemuan tersebut bisa berupa deskripsi atau gambaran suatu objek yang sebelumnya masih belum jelas. Kesimpulan tersebut diperlukan verifikasi agar data dapat diuji kecocokan dan kebenarannya.

\subsection{Kredibilitas Data}

Uji kredibilitas data atau kepercayaan terhadap data hasil penelitian kualitatif dilakukan dengan triangulasi, mengadakan member check, dan menggunakan bahan referensi.

a. Triangulasi adalah teknik pemeriksaan keabsahan data yang memanfaatkan sesuatu yang lain di luar data itu untuk keperluan pengecekan atau sebagai pembanding terhadap data itu (Moleong, 1998). Dalam penelitian ini peneliti menggunakan beberapa macam triangulasi, yaitu triangulasi teknik, triangulasi sumber dan trianggulasi waktu (Sugiyono, 2010).

1. Triangulasi teknik berarti peneliti menggunakan teknik pengumpulan data yang berbeda-beda untuk mendapatkan data dari sumber yang sama. Peneliti menggunakan wawancara mendalam, dan dokumentasi untuk sumber data yang sama secara serentak.

2. Triangulasi sumber berarti untuk mendapatkan data dari sumber yang berbeda-beda dengan teknik yang sama. 
3. Triangulasi waktu berarti data yang dikumpulkan dengan teknik wawancara di pagi hari pada saat narasumber masih segar, akan memberikan data lebih valid sehingga lebih kredibel. Selanjutnya dapat dilakukan dengan pengecekan dengan wawancara, observasi atau teknik lain dalam waktu atau situasi yang berbeda. Bila hasil uji menghasilkan data yang berbeda, maka dilakukan secara berulang-ulang sehingga sampai ditemukan kepastian datanya.

b. Mengadakan member check. Tujuan member check adalah untuk mengetahui seberapa jauh data yang diperoleh sesuai dengan apa yang diberikan oleh pemberi data. Jadi tujuan member check adalah agar informasi yang diperoleh dan akan digunakan dalam penulisan laporan sesuai dengan apa yang dimaksud sumber data atau informan (Sugiyono, 2007).

c. Menggunakan bahan referensi. Bahan referensi adalah pendukung untuk membuktikan data yang telah ditemukan oleh peneliti. Dalam laporan penelitian, sebaiknya data-data yang dikemukakan perlu dilengkapi dengan foto-foto atau dokumen autentik, sehingga menjadi lebih dapat dipercaya (Sugiyono, 2007).

\section{4. $\quad$ Result}

\subsection{Struktur Organisasi}

Menurut hasil wawancara dari bagian akuntansi dan pembukuan Bapak SR (yang tidak mau disebutkan Namanya) menyatakan bahwa dalam struktur organisasi jelas tergambarkan garis komando, wewenang dan tanggung jawab serta hubungan kerja antar bagian di dalam struktur organisasi.

Adapun mengenai apakah PDAM Buton Selatan memiliki uraian tugas dan tanggung jawab menurut hasil wawancara dari bagian administrasi keuangan Bapak EM (yang tidak mau disebutkan Namanya) menjelaskan bahwa tugas dan tanggungjawab Karyawan PDAM Buton Selatan, telah diatur berdasarkan Peraturan Perusahaan Daerah Air Minum Kabupaten Buton Selatan.

Sedangkan terkait pemisahan fungsi antara bagian penerimaan kas dengan bagian keuangan di PDAM Buton Selatan dari bagian penagihan Bapak SF (yang tidak mau disebutkan Namanya) menjelaskan bahwa secara fungsi bagian penerimaan dipisahkan dengan bagian lainnya, yang berfungsi untuk mencatat segala aktifitas penerimaan usaha. Namun secara struktural penerimaan kas masuk bagian keuangan.

Menurut teori Mulyadi (2016) dari hasil wawancara dengan bagian administrasi keuangan (Bapak EM), bagian akuntansi dan pembukuan (Bapak SR) serta bagian penagihan (Bapak SF) dalam struktur organisasi hal yang terpenting yaitu memisahkan pembagian tanggung jawab fungsional secara tegas yang didasarkan pada prinsip-prinsip: (a) harus dipisahkan fungsi-fungsi operasi dan penyimpanan dari fungsi akuntansi, (b) Suatu fungsi tidak boleh diberi tanggung jawab penuh untuk melaksanakan semua tahap suatu transaksi.

Dari hasil wawancara yang telah dilakukan dengan bagian administrasi keuangan (Bapak EM), bagian akuntansi dan pembukuan (Bapak SR) serta bagian penagihan (Bapak SF), menunjukkan bahwa di PDAM Buton Selatan memiliki struktur organisasi yang menggambarkan hubungan wewenang dan tanggung jawab serta adanya pemisahan fungsi yang jelas antara fungsi kas dan fungsi akuntansi.

\subsection{Sistem Wewenang dan Prosedur Pencatatan}

Menurut wawancara dengan Bapak SR menyatakan bahwa Laporan yang disajikan secara utuh dipertanggungjawabkan oleh masing-masing petugas yang berhubungan dengan penerimaan kas sampai dengan tingkat pimpinan yang bertugas menangani penerimaan kas. 
Menurut teori Jerry J. Weygandt, et al (2007) dari hasil wawancara dengan bagian akuntansi dan pembukuan (Bapak SR) untuk dapat mencapai tujuan pengendalian akuntansi, suatu sistem harus memenuhi prinsip dasar pengendalian intern yang meliputi pembentukan tanggung jawab dimana karakteristik penting dalam pengendalian intern yaitu penyerahan tanggung jawab kepada karyawan tertentu. Pengendalian akan paling efektif jika seseorang yang bertanggung jawab pada sebuah pekerjaan tertentu.

Mengenai petugas/karyawan yang menangani bagian penerimaan kas Bapak SF kemudian menjelaskan bahwa Petugas Penerimaan (Petugas Penagih) hanya melakukan Penagihan ke masing-masing Pelanggan dan Menyetorkan hasil penagihan ke Bendahara Penerimaan. Dan setelah kas diterima oleh Bendahara penerimaan selanjutnya menyetorkan ke pemegang kas besar / Bank.

Menurut Mulyadi (2016) menyatakan bahwa prosedur pencatatan yang baik akan menjamin data yang direkam dalam formulir dicatat dalam catatan akuntansi dengan ketelitian dan keandalan yang tinggi. Dengan demikian sistem otorisasi akan menjamin dihasilkannya dokumen pembukuan yang dapat dipercaya bagi proses akuntansi.

Hasil wawancara yang telah dilakukan dengan bagian akuntansi dan pembukuan (Bapak SR) dan bagian penagihan (Bapak SF), menunjukkan bahwa di PDAM Buton Selatan memiliki sistem wewenang dan prosedur pencatatan yang menggambarkan adanya otorisasi dari pihak yang berwenang pada setiap transaksi, salah satu contoh pada fungsi penagihan dimana dalam melakukan penagihan hanya atas dasar daftar piutang yang dibuat oleh fungsi akuntansi karena agar tidak terjadi penagihan tanpa adanya surat tagihan.

\subsection{Praktek Yang Sehat}

Dalam kajian teori Mulyadi (2016) ada beberapa cara yang seharusnya dilakukan perusahaan dalam menciptakan praktik yang sehat pada perusahaan: a) Penggunaan formulir bernomor urut tercetak yang pemakaiannya harus dipertanggungjawabkan oleh yang berwenang, b) Pemeriksaan mendadak (suprised audit), c) Perputaran jabatan (job rotation), d) Secara periodik diadakan percocokan fisik kekayaan dengan catatannya.

Hal ini didasarkan pada wawancara yang dilakukan pada bagian penagihan Bapak SF menjelaskan bahwa Setiap dokumen yang berhubungan dengan penerimaan maupun kegiatan lainnya yang berhubungan dengan pembukuan, diberi nomor urut atau referensi dan dicatat berdasarkan tanggal penerimaan. Nomor urut / referensi tersebut digunakan untuk memudahkan dalam mengidentifikasi setiap transasksi penerimaan.

Adapun mengenai pemeriksaan mendadak Bapak EM menjelaskan bahwa Pemeriksaan mendadak dilakukan karena kegiatan ini merupakan salah satu tugas pengawasan guna menghindari resiko penyelewengan penerimaan kas.

Selanjutnya, Bapak EM berpendapat mengenai apakah dilakukan job rotasi pada bagian-bagian tertentu menyatakan bahwa Pelaksanaan rotasi, dilakukan dengan mengevaluasi kinerja pegawai.

Sedangkan terkait dengan apakah PDAM Buton selatan melakukan pencocokan fisik kekayaan dengan catatan bagian keuangan hasil dari penerimaan kas secara periodik Bapak SR selanjutnya menjelaskan bahwa Pelaksanaan Opname Aktiva Tetap maupun Aktiva Lancar dilakukan secara Periodik.

Menurut hasil wawancara yang telah dilakukan oleh Bapak EM, Bapak SR, dan Bapak SF, menunjukkan bahwa di PDAM Buton Selatan memiliki praktik yang sehat yang menggambarkan adanya tanggung jawab yang telah ditetapkan dari pihak yang berwenang pada setiap transaksi. 


\subsection{Karyawan Yang Mutunya Sesuai Dengan Tanggung Jawabnya}

Dalam kajian teori Mulyadi (2016) Karyawan yang jujur dan ahli dalam bidang yang menjadi tanggung jawabnya akan dapat melaksanakan pekerjaanya dengan efisien dan efektif. Untuk mendapatkan karyawan yang kompeten dan dapat dipercaya berbagai cara dapat ditempuh: a) Seleksi calon karyawan berdasarkan persyaratan yang dituntut oleh pekerjaannya. Untuk mamperoleh karyawan yang mempunyai kecakapan sesuai dengan tuntutan tanggung jawab yang akan dipikulnya, manajemen harus mengadakan analisis jabatan yang ada dalam perusahaan dan menentukan syarat-syarat yang dipenuhi oleh calon karyawan yang akan menduduki jabatan tersebut, b) Pengembangan pendidikan karyawan selama menjadi karyawan perusahaan, sesuai dengan tuntutan perkembangan pekerjaannya.

Hal ini didasarkan pada wawancara yang dilakukan oleh Bapak EM menjelaskan bahwa Latar belakang pendidikan dan pengalaman kerja merupakan tolak ukur yang paling pokok dalam setiap perekrutan karyawan.

Selanjutnya terkait dengan pelatihan untuk karyawan baru yang dilakukan di PDAM Buton Selatan Bapak SR menyatakan bahwa Pelatihan yang dilakukan bagi karyawan baru dilakukan secara internal.

Selain itu, menurut kajian teori William et al (2014) pemantauan pengendalian merupakan sebuah proses untuk menilai kualitas kinerja pengendalian internal dari waktu ke waktu. Ini melibatkan penilaian rancangan dan pengendalian operasi secara tepat waktu dan mengambil tindakan korektif yang diperlukan. Pemantauan dapat dilakukan melalui kegiatan yang sedang berlangsung atau evaluasi terpisah. Manajemen dapat menggunakan auditor internal atau personel yang melaksanakan fungsi yang sama untuk memantau efektivitas operasi pengendalian internal. Hal ini didasarkan pada wawancara Bapak EM mengenai pemeriksaan internal atas transaksi penerimaan kas menyatakan bahwa Pelaksanaan pemeriksaan internal dilakukan oleh pimpinan yang bertanggung jawab atas kegiatan penerimaan kas, akan tetapi yang melakukan pemeriksaan internal bukanlah orang yang mempunyai pengalaman.

Hasil wawancara yang telah dilakukan oleh Bapak EM dan bapak SR, menunjukkan bahwa di PDAM Buton Selatan dalam menyeleksi tenaga kerja atau karyawan berdasarkan kebutuhan dan standar yang telah ditetapkan untuk mendapatkan karyawan yang sesuai dengan bidangnya dan karyawan baru akan mendapatkan pelatihan.

\subsection{Evaluasi Penerapan Sistem Pengendalian Intern Penerimaan Kas}

Penerapan sistem pengendalian intern yang diterapkan oleh PDAM Buton Selatan, sudah dijalankan dengan baik dan sesuai dari segi: a) Struktur Organisasi yaitu Pemisahan fungsi atau pembagian tanggung jawab fungsional pada PDAM Buton Selatan baik sekali, dimana perusahaan menetapkan dan menerapkan struktur organisasi yang menggambarkan hubungan wewenang dan tanggung jawab serta adanya pemisahan fungsi yang jelas antara fungsi kas dan fungsi akuntansi. b) Sistem Wewenang dan Prosedur Pencatatan dimana PDAM Buton Selatan memiliki sistem wewenang dan prosedur pencatatan baik sekali yang menggambarkan adanya otorisasi dari pihak yang berwenang pada setiap transaksi dimana pada fungsi penagihan dalam melakukan penagihan hanya atas dasar daftar piutang yang dibuat oleh fungsi akuntansi karena agar tidak terjadi penagihan tanpa adanya surat tagihan. c) Praktek Yang Sehat yaitu formulir yang berhubungan dengan penerimaan kas memiliki nomor urut tercetak, pemeriksaan mendadak, dilakukan job rotasi, dan pencocokan fisik kekayaan dengan catatan bagian keuangan yang hasil dari evaluasi menyatakan sesuai dengan teori yang ada.

Namun jika dinilai berdasarkan unsur-unsur sistem pengendalian intern dari prinsip-prinsip pengendalian intern yang efektif dalam hal penerimaan kas masih terdapat adanya kelemahan atau belum sesuai yaitu dari segi karyawan yang mutunya 
sesuai dengan tanggung jawabnya dan perlu di evaluasi yaitu dalam melakukan pemeriksaan internal atas transaksi penerimaan kas masih dilakukan oleh orang yang tidak berpengalaman.

\section{Conclusion}

Berdasarkan hasil pembahasan yang telah diuraikan oleh peneliti, maka kesimpulan dari penelitian ini adalah sebagai berikut:

1. Sistem pengendalian intern penerimaan kas pada PDAM Buton Selatan sudah cukup efektif dan memadai dengan memenuhi lima unsur pengendalian intern yaitu, struktur organisasi, sistem wewenang dan prosedur pencatatan, praktik yang sehat serta karyawan yang mutunya sesuai dengan tanggung jawabnya. Hal ini ditandai dengan adanya pemisahan tugas, tanggung jawab dan batasan wewenang yang jelas pada setiap unit kerja yang terdapat pada perusahaan. Dengan demikian pengendalian intern penerimaan kas pada PDAM Buton Selatan telah sesuai dengan teori.

2. Secara keseluruhan PDAM Buton Selatan sudah memiliki sistem pengendalian intern yang optimal. Perusahaan telah banyak menerapkan sistem pengendalian intern yang sesuai dengan teori-teori yang dibuat para ahli.

3. Penerapan sistem pengendalian intern penerimaan kas pada PDAM Buton Selatan berada di kisaran poin $61 \%$ - 80\%, dengan total bobot penilaian hasil kuesioner adalah $79,16 \%$ yang berarti perusahaan mendapat penilaian "Baik" dengan perbandingan teori yang dilakukan.

\section{References}

Amin Widjaja Tunggal. 2013. Pengendalian Internal Mencegah dan Mendeteksi Kecurangan. Jakarta: Harvarindo.

Anastasia dan Lilis Setiawati. 2015. Sistem Informasi Akuntansi, Perancangan Proses dan Penerapan. Jakarta: Andi.

Indriantoro, Nur dan Supomo, Bambang. 2009. Metodologi Penelitian: Untuk Akuntansi \& Manajemen. Edisi Pertama. Yogyakarta: BPFE.

Miles, M.B dan A.M Huberman. 2014. Qualitative Data Analysis. Beverly Hills: Sage Publication Inc.

Moleong, Lexy J. 1998. Metodologi Penelitian kualitatif. Cetakan ke sembilan ed. Bandung: Remaja Rosdakarya Offset.

Mulyadi. 2002. Auditing. Edisi Keenam. Jakarta: Salemba Empat.

Mulyadi. 2016. Sistem Akuntansi. Edisi Keempat. Jakarta: Salemba Empat.

Romney, Marshall B; dan Paul John Steinbart. 2015. Sistem Informasi Akuntansi. Edisi Ketiga Belas. Jakarta: Salemba Empat.

Sugiyono. 2007. Metode Penelitian Kuantitatif Kualitatif dan R \& D. Bandung: Elfabeta.

Sugiyono. 2010. Metode Penelitian Bisnis: Pendekatan Kuantitatif, Kualitatif dan R\&ED. Bandung: Alfabeta.

Sugiyono. 2014. Metode Penelitian Kuantitatif Kualitatif dan R\&D. Bandung: Alfabeta. Theodorus M, Tuanakotta. 2014. Audit Berbasis ISA (International Standards on Auditing). Jakarta: Salemba Empat.

Weygandt Jerry J, et. al. 2007. Accounting Principles, Terj. Ali Akbar Yulinto, Wasilah, dan Rangga Handika. Edisi Ketujuh. Jakarta: Salemba Empat.

William F. Messier, Steven M. Glover, Douglas F. Prawitt. 2014. Jasa Audit dan Assurance: Pendekatan Sistematis. Edisi 8. Buku 1. Jakarta: Salemba Empat. 